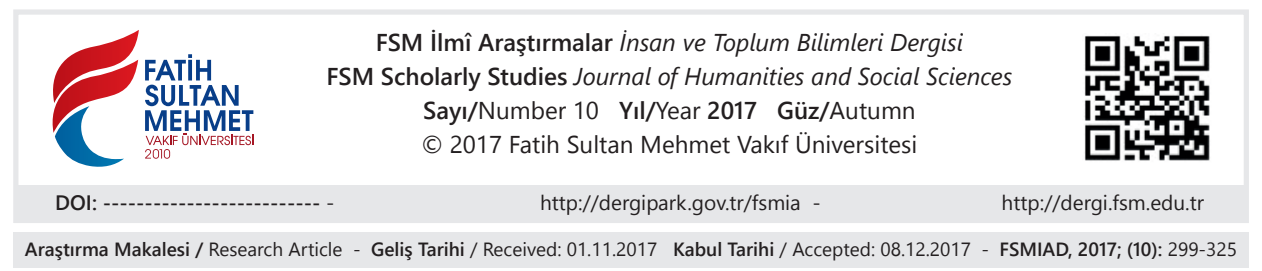

\title{
Sabri F. Ülgener, İktisadi Hayat, Tasavvuf, Geleneksel Dünya ve İslâm'ın Yeni Teolojisi
}

$\ddot{O} \mathbf{z}$

Ahmet Tak*

Sabri F. Ülgener iktisat tarihine yönelik çalışması ile Türk tarihçiliği ve sosyolojisi içinde oldukça istisnai ve mümtaz bir yerde durmaktadır. Yaşadığı dönemde, Türk düşünce ve bilim hayatı açısından oldukça yeni olan iktisadi hayat ve zihniyet arasındaki ilişkiyi eserlerinin temel meselesi olarak ele almış ve düşünce ufkumuzu genişletmiştir. Yine de Ülgener'i, bu meseleyi nihayete erdiren bir kişi olmaktan ziyade yeni bir problem alanını Türk düşüncesine takdim eden birisi olarak görmemiz gerekir. Makalede Ülgener'in neleri vukufla açıklayabildiği ve nerelerde yetersiz kaldığg ve ayrıca çalışmasını yönlendiren temel siyasi saikın ne olduğunu ortaya konmaya çalışılacaktır. Son olarak Ülgener'in analizinin sosyolojik teori içinde nereye yerleştirilebileceği tespit edilmeye çalışılacaktır.

Anahtar Kelimeler: Sabri Ülgener, zihniyet, tasavvuf, geleneksel hayat, ekonomik hayat.

\section{Sabri F. Ülgener, Economic Life, Sufizm, Traditional World and the New Theology of Islam}

\section{Abstract}

Sabri F. Ülgener stands in a very exceptional and prestigious place within Turkish historiography and sociology with his work on the economic history of Turkey. As the main issue of his work, Ülgener introduced a new area of study to Turkish intellectual and scientific life: the relation between economic life and mentality. He, it is fair to say, singlehandedly expanded the horizons of our thought in this area. Nevertheless, we should consider Ülgener as a person who presents this new field of problem to Turkish thought rather than a person who says the last word on this matter or solves the problem. This article tries to demonstrate what Ülgener is able to explain explicitly and where he is inadequate as well as the basic political motive that drives his work. Lastly, it will be tried to define the position of Ülgener's work in sociological theory.

Keywords: Sabri Ülgener, mentality, sufizm, traditional life, economic life.

* Yrd. Doç. Dr., Çankırı Karatekin Üniversitesi Edebiyat Fakültesi Sosyoloji Bölümü, Çankır1/

Türkiye, ahmettak@gmail.com, orcid.org/0000-0001-7989-7620 


\section{Giriş}

Sabri F. Ülgener iktisat tarihine yönelik çalışması ile Türk tarihçiliği ve sosyolojisi içinde oldukça istisnai ve mümtaz bir yerde durmaktadır. Yaşadığ dönemde, Türk düşünce ve bilim hayatı açısından oldukça yeni olan iktisadi hayat ve zihniyet arasındaki ilişkiyi eserlerinin temel meselesi olarak ele almış ve düşünce ufkumuzu genişletmiştir. Yine de Ülgener'i, bu meseleyi nihayete erdiren bir kişi olmaktan ziyade yeni bir problem alanını Türk düşüncesine takdim eden birisi olarak görmemiz gerekir. Ancak Ülgener'in takdim etmiş olduğu bu alanda kendisinin iki eserinin üzerine çok fazla yeni bir şeyin eklenmiş olduğunu da maalesef göremiyoruz. Bunun nedenleri ayrıca tartışılabilir. Ancak biz bu çalışmada Ülgener'in iktisadi hayat, zihniyet ve din konusunda neleri vukufla açıklayabildiği ve nerelerde yetersiz kaldığı ve ayrıca çalışmasını yönlendiren temel siyasi saikın ne olduğunu ortaya koymaya çalışacağız. Ayrıca sosyoloji açısından Ülgener'in analizinin kısa bir teorik eleştirisini gerçekleştirmeye çalişacağız.

Çalışma daha çok Ülgener'in İktisadi Çözülmenin Ahlâk ve Zihniyet Dünyası adlı eserinin üzerine yoğunlaşacaktır. Ülgener kendi teorik perspektifini bu eserinde temellendirmiş ve aynı perspektifi bazı hususlardaki vurgularını kısmen biraz daha yumuşatarak Zihniyet ve Din: İslâm, Tasavuf ve Çözülme Devri İktisat Ahlâkı isimli kitabında devam ettirmiştir. Ülgener'in perspektifini ve belli başlı temel kavramlarını ortaya koyduktan sonra genel bir değerlendirilmesi ve eleştirisi yapılarak, sosyoloji teorisi içinde nereye yerleştirilebileceği tespit edilmeye çalışılacaktır.

\section{Ülgener'in Amacı ve Yöntemi}

Ülgener'in analizi boyunca cevaplarını arayacağını söylediği iki temel soru şunlardır: Kültür tarihi boyunca akisleri ile birlikte, Ortaçağ sonlarından başlayarak iktisat ahlakı ve zihniyeti nasıl bir cehreye sahiptir? Asırlar boyu bu zihniyeti besleyen, şekillendiren ve yayan din dahil değişik etkenler nelerdir? ${ }^{1}$ Ülgener için tarihi bir zihniyetin analizi sadece tarihe yönelik bir ilgi ve alakadan ibaret değildir. Bugünkü insanın iç dünyasının belli çizgilerini geçmişin fizyonomisi içinde teşhis etmek bizi şaşırtmamalıdır der. ${ }^{2}$.

Ülgener'e göre bu ortaçağ zihniyeti günümüzde de varlığını devam ettirmektedir ve tezahürlerini ancak devrin ahlaki, dini, edebi v.b. kaynaklardaki ifadeler va-

1 Sabri F. Ülgener, İktisadi Çözülmenin Ahlak ve Zihniyet Dünyası, İstanbul: Der Yayınları, 1991, s. 16

2 Ülgener, a.g.e., s. 18 
sitası ile dolaylı olarak kavrayabiliriz. ${ }^{3}$ Bundan dolayı, Ülgener yukarıdaki sorulara cevap ararken içinde zihniyetin akislerini barındıran çağın sanat eserlerine hususi bir önem atfeder. Dönemin insanının yüz ve karakter çizgilerinin mümkün mertebe yakalanmasında sanat eserlerinin önemli olduklarını savunur. Bu sanat eserleri, "(n)azım veya nesir halinde tasvirler, mesneviler, divan ve destanlar, hiciv ve mizah yollu takllmalar, hikayeler v.s. ”dir. Ülgener üst düzeydeki entelektüel eserlerden ziyade daha alt düzeyde üst düzeydekilerin dile getirdiği fikirleri popülerleştirip halka yayan dolayısı ile halkın temas ettiği ve halka temas eden eserleri analizi için daha uygun görür ki bu Max Weber'in Protestan Ahlakı ve Kapitalizmin Ruhu kitabında kullandığı yöntemle uyum içindedir. Ülgener'in çalışması tamamen olmasa da kısmen bir tür folklorik nitelik gösterir. Ülgener geçmişe yönelik idealleştirici her türden romantik bakışı bertaraf etmesine rağmen, yine de romantik tarihçiliğin sunduğu imkânlardan faydalanır. Hem folklor araştırmalarının başlaması hem de tarihçilik mesleği içinde folklorik unsurların dikkate alınması Alman romantik geleneğinin etkisi ile gerçekleşmiştir. Geçmişi idealleştirmemesinin yanı sıra pastoralizme yönelmemesi ve kalkınmacı problematiği Ülgener'i romantiklerden ayırır. Çalışmasında bir eksiklik olarak değerlendirilen köylüleri dikkate almaması ${ }^{4}$ kısmen de bundan kaynaklanır. Ülgener'i tam anlamı ile folklorik bir bakış açısına sahip olmaktan uzaklaştıran, iktisat tarihi çalışmaları açısından önemini kabul etmekle birlikte, kendi amacı ile doğrudan alakalı olmadığını düşündüğü halk edebiyatından ziyade divan edebiyatını dikkate almış olmasıdır.

Ülgener "tek ve somut vak'alarla değil, çă̆ın ve çevrenin umumi havası ile ilgileneceğimiz için baş vuracă̆ımı kaynaklar halk ve destan edebiyatından çok klasik edebiyata-özellikle divan edebiyatına-ait eserler olacaktır" demektedir. ${ }^{5}$ Ancak bu açıklama yeterince tatmin edici değildir. Halk edebiyatını bir kenara terk etmesi daha çok Weber'in çizdiği yörüngeyi takip etmesinden kaynaklanıyor gibi görünmektedir. Weber modern kapitalizmin gelişmesinde kırsal unsurlardan ziyade ortaçağ şehir hayatı ile ilgilenmişti. Benzer şekilde Ülgener de, şehirlerde oluşan iktisadi zihniyetin analizi ile alakadar olmaktadır. Edebi metinlerin bir veri olarak kullanılmasında ayrıca Werner Sombart'ın konuya ilişkin yaklaşımı da etkili olmuştur.

Ülgener'in bakış açısındaki önemli noktalardan biri ‘divan' edebiyatını halktan kopuk sadece üst sinfflara ait bir olgu olarak görmemesidir. Divan edebiyatı

3 Ülgener, a.g.e., s. 36-37

4 Dursun “Sabri F. Ülgener' in Türk Düşünce Kültüründeki Yeri”, Doğu Batı, Y11 3, Sayı 12, 2011, s. 188

5 Sabri F. Ülgener, İktisadi Çözülmenin Ahlak ve Zihniyet Dünyası, İstanbul: Der Yayınları, 1991, s. 17 
birçok noktada doğrudan veya dolaylı şehirde yaşayan halk ile temas halindedir ve insanlara gündelik yaşayışları içinde kullanabilecekleri ifadeleri hazır kalıplar halinde sunmaktadır. Aksi takdirde çağın zihniyetini divan edebiyatına ait eserler üzerinden analizi abesle iştigal anlamı taşırdı.

Ülgener sanat eserlerini çağın ve çevrenin zihniyetinin deyim ve söyleyişler halinde yankılandıkları belgeler olarak görür. Ancak, çağın zihniyeti bu eserlerde dağınık şekillerde bulunurlar. Bundan dolayı araştırmacı tarafından bütünlüklü bir şekilde sistemleştirilmeleri gerekir. Çağın insanını ve zihniyetini, bütün bu akisleri bir birine bağlamak bir 'inşa etmek' faaliyetidir. Bu yeniden inşa etme faaliyeti Ülgener tarafından Weber'in ideal tip anlayışı yoluyla gerçekleştirilir. Ü1gener "arşivci-pozitivist tarihçinin hassas ölçü ve tartılarının" konunun genişliği ve sınırlarının muğlaklığından dolayı zihniyet analizi için uygun olmadığını savunur. ${ }^{6}$ Yine de zihniyet analizi için belli morfolojik araştırmaların daha önceden yapılmış olması zaruri bir şarttır. Zihniyet analizi iktisat tarihinin 'concret' (müşahhas) müesseselerinin dışında kaypak bir zemin üzerinde gerçekleştirilebilir. Zihniyet araştırmaları, tamamen pozitif tarih incelemelerinin dışında olmamakla birlikte daha çok "sosyolojik bir toplu görüşe ve geniş bir tarih felsefesi planına" bitişik olan meseleler alanı ile ilişkili olarak yürütülebilecektir. ${ }^{7}$

Ülgenerin yönteminde öne çıkan bir diğer husus, Weber'in ideal tip yöntemini kullanılmış olmasıdır. Weber 'ideal tipi' sosyal çalışmanın amacı olmaktan ziyade sosyal gerçekliğin tahlilinde kullanılacak araçlar olarak tanımlar. İdeal tipler sosyal gerçeklikten mantıki soyutlamalarla ve saflaştırma yoluyla elde edilmesine rağmen sosyal gerçekliği doğrudan temsil etmezler. Sosyal olgular hiçbir zaman ideal tipler içinde olduğu kadar saf biçimde sosyal dünyada var olmazlar. Sosyal olgular her zaman ideal tiplerden sapmalar gösterirler. İdeal tipler bize olgular ve tarihi dönemler ve değişik coğrafyalar arasında karşılaştırmalar yapabilme imkânı sunarlar. Ülgener Weber'in ideal tip görüşüne bağlı olarak tarihi dönemselleştirmede ve insan kişiliklerini tanımlamada belli tipleştirmeler yapmış ve onlar üzerinden temel problemini izah etmeye çalışmıştır.

\section{Zihniyet ve İnsan Tipleri}

Ülgener'e göre iktisadî hayat, klasik iktisatçıların ve tarihçi okulun basit ve dar şemalarıyla anlaş1lamayacak ölçüde geniş ve engin bir çeşitlilik gösterir. Yüzeyde görünen şekil ve madde yığınının altında onlara gerçek renk ve manasını veren geniş bir ruh ve zihniyet dünyası yer alır. ${ }^{8}$ Batı'dan aynı üretim ameliye-

\footnotetext{
6 Ülgener, a.g.e., s. 17-18

7 Ülgener, a.g.e., s. 19

8 Ülgener, a.g.e., s. 12
} 
sini ve hukuk sistemini olduğu gibi aktaran ülkelerde iktisadi hayatın sonuçları farklılık gösteriyorsa, Ülgener'e göre bunun sebebini daha altta yatan zihniyet ve tutum farklarında yani insan tipinde aramak gerekmektedir. İktisadi ilişkilerin çerçevesini belirleyen formel-hukuki ilişkilerin daha derininde engin bir "duyuş ve düşünüş" dünyası yer almaktadır. Hülasa der Ülgener, iktisadi hayat "yalnızca dış verilerin bir araya gelişinden ibaret bir madde dünyası değildir. Bütün o yl$\breve{g}$ ınların altında ve gerisinde kendine has tavır ve davranışlart ile insan gerçeği yatar."

Ülgener'e göre zihniyet araştırmaları iki noktada toplanabilir: İlk olarak dönemin ve "çevrenin iktisat ahlakını ve zihniyetini az çok geniş ve toplu bir tablo halinde belirlemek!'. Böyle bir tablo çağın ve çevrenin tipik insanının davranış şekillerini ve dünya görüşünü bir araya getirecektir. Bu nedenle, ister istemez sentetik ve kısmen suni bir derleme niteliği taşıyacaktır. Elbette ki bu kısmi sunilik Ülgener'in Weberci ideal tip anlayışına bağlılığından ortaya çıkacaktır. İkinci olarak belli bir çağın zihniyetinin oluşma süreci, geçirdiği değişimler, üstesinden geldiği mukavemetler, alakalı olduğu değişik din ve itikat zümreleri gibi faktörlerle ilişkisi içinde ele alınır. ${ }^{10}$ Araştırmanın ilk aşamasında, manevi ilimlerin (kültür ilimlerinin) usul ve araçları geniş ölçüde kullanılabilir. Araştırmanın ikinci aşaması oldukça geniştir ve bir dönemin zihniyetinin oluşumunda etken olan iç ve dış amillerin tespit edilmesini içerir. Belli bir yaşayış ve davranış tarzının oluşmasında (şarklı için bu pasif-atıl bir hayat tarzıdır) iklim, siyasi baskı gibi dış unsurlar müessir olabilirler. Ancak ası önemli etkiye sahip olan manevi-dini faktörlerdir ki bunlar basit davranış kalıplarının ötesinde, ahlaki ifade kalıpları içinde bir dünya görüşünün bireylerin zihniyetine nakşolunmasında oldukça tesirlidirler. ${ }^{11}$

Ülgener'e göre büyük ahlak sistemleri, hiyerarşik olarak değerlerin insicamlı ve ahenkli bir şekilde ifade edildiği homojen mecmu bütünlerdir. Din ve ilahiyat, dönemin icabı olarak, bu ahengi sağlayan temel unsurlardır. Bu çerçeve içinde diğer hadiseler gibi fert ve cemiyet münasebetleri de yerlerini ve anlamlarını kazanırlar. "Değer ölçüleri de, aynı fikre uyarak, dünya kaygısının ve maddi alâkaların mümkün olduğu kadar uzağında, dar ve kapalı inziva âleminin huzur ve sükûnu içinde toplanmıştır. Ortaçağ ahlâkını, şu vasıfları ile, kendi içine çevrili, dış aleme azami ölçüde mesafeli bir dünya görüşünün yer yer dini-mistik duygularla örülü ifade topluluğu diye hülâsa etmek yanlış olmayacaktır."12

9 Ülgener, a.g.e., s. 12

10 Ülgener, a.g.e., s. 13

11 Ülgener, a.g.e., s. 14

12 Ülgener, a.g.e., s. 52 
Ahlak sistemleri her ne kadar dışa kapalı görünseler de daha önceki dönemlere ait fikirlerin yeni dönemle yoğurulup kaynaştırılmasından oluşurlar. Sürekli olarak dış hayatla ve içtimai zümrelerle temas içinde bulunurlar. Ahlak telakkilerinin 'alt yapısı' asırlar boyu devam ede gelen kapalı hayat biçimleri olan sınıf ve tabaka düzeninin şuursuzca biriktirmiş olduğu temayüller ve alışkanlıklar tarafından şekillendirilirler. Ülgener bu temayülleri ‘temel kıymetler' diye isimlendirir. Hayatın hakiki zaruretlerinden, hayati güdülerden doğup geldikleri için çoğu skolastik düşünceden, ilahiyat sistemlerinden daha eskidir. Dahası bu sistemler tarafından yeniden şekillendirmeye karşı da belli bir mukavemet gösterirler. ${ }^{13}$ Ülgener dini bir hüviyet gösterdiklerinde bile bu temel kıymetlerin gerçekte dinle çok fazla alakalarının olmadığını ima eder görünmektedir.

Ülgener'in ideal tipleştirmesinde iki tip insan yer alır: 'Kapitalist' ve 'pre-kapitalist' insan tipi. Hem kapitalist insan hem de pre-kapitalist insan, içinde yaşadıkları dış kalıpların basit bir fonksiyonu değillerdir. Çevre ve eşyaya yönelik belli bir bakış açısı ile yani bir iç dünyası ile varlık kazanırlar. "Kaldı ki, hisler ve duygular tarihin akışına zaman zaman bir "eser"den daha fazla bir varlık, bazen gerçek bir "müessir" olarak katılmışlardır."14 Ülgener'e göre, günümüz de zihniyet araştırmaları iktisat tarihinin diğer konuları ile aynı seviyede yer almaktadır.

Pre-kapitalist insan tipinin özelliği: "Bol ve ferah yaşamanin tattıracă̆ haz ve zevke (ya da özlemine) hiçbir zaman yabancı olmamakla beraber, o uğurda acele ve telaştan hoşlanmayan, yolunu ve yönünü tayinde göreneğe bağhl, işinde ve hesabında götürü bir insan!' olmasıdır. Gücü yettiğince bol ve gösterişli tüketim arzusunun üretim çabasının önünde ve ilerisinde olması bugünkü Türk insanı için de geçerlidir. Çözülme devri insanının temel özelliği "her şeyi kendi üstünde ve dışındaki kuvvetlerle (ister göktekinin "rahmet" i, ister yerdekinin himmeti ile) düzenlenmiş görme alışkanlığından gelen rehavet, yavaşlık ve ağırlık” oluşturmaktadır. ${ }^{15}$

\section{Ortaçağın Zihniyet Dünyası}

Ülgener geleneksel Osmanlı dünyasına ve zihniyetine dair görüşünü oldukça açık bir şekilde ortaya koyar:

"Başta, imtiyazlı sınıfın ağalık ve efendilik bilinci; ihtişam ve tahakküm hevesi; onların altında, geniş halk tabakalarının dar, statik hayat anlayışı; nihayet en altta, asırlık telkinlerle boyun eğdirmeye alıştırılmış köylü sınıfının te-

13 Ülgener, a.g.e., s. 53

14 Ülgener, a.g.e., s. 13

15 Sabri F. Ülgener, Zihniyet ve Din: İslam, Tasavvuf ve Çözülme Devri İktisat Ahlakı, İstanbul, Derin Yayınları, 2006, s. 6 
vekkül ve teslimiyeti... Esnafta: Topluluk ve dayanışma duygusu; geleneksel iş ve sanat anlayışı v.s."

Ülgener geleneksek Şarklı zihniyetinin oluşmasında din ve tasavvufun oldukça müessir amiller olduğunu düşünür. "Ş̧arkl ruhunda tevekkül ve teslimiyet, aslında hangi kökten gelmiş olursa olsun, ancak din ve tasavvufla yoğrulup ifade şeklini kazandıktan sonradır ki, hakiki derinliğine varmış ve tamamlanmış sayllabilir..." demektedir. ${ }^{17}$ Ayrıca, Ülgener'e göre gündelik hayatta karşılaştığımız deyimlerin birçoğu ortaya çıkışları araştırıldığında köklerinin dini mistik itikatlara dayandığ 1 görülür. Zamanla dini hüviyetlerini kaybederek içi boş kalıplar halinde günümüze kalmışlardır. Bundan dolayı iktisat tarihçisi, kendi alanı ile alakalı meselelerin kökenini araştırırken iktisadi rasyonel düşünce ile açıklanması imkânsız amilleri de dikkate almak zaruretindedir. ${ }^{18}$

Ülgener'e göre Batı ve Şark farklı tarihi dönemler içinde harekette bulunmaktadırlar. Batı modern dönemlerle birlikte Ortaçağdan çıkarken, Osmanlı dünyası tam tersi bir istikamette yol almaktadır ve ortaçağ değerlerine geri dönmektedir. Ülgener bu süreci “ortaçağlaşma” veya daha hususi bir şekilde "esnaflaşma” diye isimlendirmektedir. Sürecin temel hususiyetlerini belirlerken esnaflaşmanın yanı sıra gelenekçilik ve ağalık ve efendilik şuurunu da vurgular:

"Her şeyden önce, parlak bir ticaret devrinin sonu. Teşebbüs formlarında yer alan "esnaflaşma"; değer anlayışında da aynı surette kapanma ve katılaşma; en küçük bir yeniliğe göz yummayan meslek ve sanat taassubu (gelenekçilik). Nihayet Feodal hayatın asırdan asra aktardığ a ağalık ve efendilik şuuru: Bol tüketimin, hele görünüş ve gösterişin çekici etkisinden hiçbir zaman uzak kalmamakla beraber, kendini gündelik iktisadi kaygıların üstünde görmeğe alışık, üretimi ve değer yaratmayı kendinden başkalarının sırtına yüklenmiş görmek isteyen zihniyet!"'19

Ülgener 'iktisat ahlakı' ile 'iktisat zihniyetini' bir birinden ayrı tutar. İktisat ahlakı, iktisadi hayat içinde uyulması gereken normların ve kuralların bütünü ifade eder. İktisat zihniyeti ise kişinin davranışlarını yönlendiren değer ve inançların tümünü ifade eder. İktisat zihniyeti açısından, değer ve inançların iç dünya ile sınırlı kalmayıp davranışlarda fiilen tebarüz etmesi önemlidir. Ülgener'e göre, ahlak ve zihniyet, kültürümüzün alttan üste kaderini belirleyen ikili bir tabaka-

16 Sabri F. Ülgener, İktisadi Çözülmenin Ahlak ve Zihniyet Dünyası, İstanbul: Der Yayınları, 1991, s. 12

17 Ülgener, a.g.e., s. 14, dip not 1

18 Ülgener, a.g.e., s. 15

19 Ülgener, a.g.e., s. 15 
laşmanın kökenini oluşturur. "Altta, temel değerleri ve politik yapısı ile "ortaçağlaşmış" bir dünyanın iktisat ahlakı" yer alır. ${ }^{20}$ Onun üstünde zamanla oluşan tabaka ise çözülme devri zihniyetidir.

Ülgener 'çözülme devri' şeklinde yaptığı dönemleştirmeyi, Osmanlı tarihi için kullanılan 'duraklama ve gerileme dönemi' ifadesinden farklı olarak kullandığını söyler. Ülgener açısından Osmanlının siyasi alanda parlak yükselme dönemi ile çözülme (veya ortaçağlaşma) dönemi birbiri ile aynı zamana denk gelmektedir. Bu bize Ülgener'in iktisadi çöküşü açıklarken siyaset konusu ile niçin çok fazla ilgilenmediğinin de ip uçunu verir.

Ülgener bu noktada siyasi gelişmelere oldukça büyük önem atfeden Weber'den ziyade Henri Pirenne'nin Karolenjlere ve Şarlman'a yönelik değerlendirme şemasını takip eder görünmektedir. Pirenne de aslında Weber gibi Orta Çă̆ özerk şehir yapılarının gelişim çizgisini takip ederken siyasi amiller ve gelişmelere hususi bir önem atfeder. Ancak Karolenjleri değerlendirmesi diğer tarihçilerin bakışından farklılık arz eder. Tarihçilerin parlak bir canlanma devri olarak gördükleri Karolenj dönemini Pirenne, ${ }^{21}$ bütün siyasi ve kültürel gelişmelere rağmen, bir tür içe kapanma, denizle olan bağın ve ticaretin kopmasına bağlı olarak bir kara imparatorluğunun ortaya çıkışı ve iktisadi hayat açısından bir gerileme olarak görür. Karolenjlerin durumunda olduğu gibi, Ülgener açısından Osmanlılar siyasi bir gelişme ve genişleme içinde bulunurken, iktisadi hayat çoktan tedrici ama kararlı bir şekilde çözülmeye başlamış bulunmaktadır.

İktisadi hayatta bir durgunluğun ve gerilemenin başlamasının bir nedeni olarak, Ülgener dünya ticaret yollarının Akdeniz havzasından Atlantik kıyılarına kaymasını görür. Ticaret yollarının değişmesi sermaye ve teşebbüsün Batı Avrupa limanlarında temerküzüne yol açmıştır. Bunun sonuçları hem Akdeniz, hem Yakın-Doğu, hem de Osmanlı devleti açısından yıkıcı olmuştur. Osmanlı ricalinin Akdeniz'i tekrar canlandırma teşebbüsleri gidişatın seyrini durdurmaya ve değiştirmeye muktedir olamamıştır. Ticaret yollarının değişmesini ve bunun sonuçlarını dikkate alması ve ayrıca zihniyet ve iktisat ilişkisini daha geniş bir coğrafya içinde ve değişik tabakalarla irtibatlarının analizini daha tafsilatlı yapıyor olması, Ülgener'i Weber'den ayıran bir farklılık olarak değerlendirilmektedir. ${ }^{22}$ Ülgener bununla Weber'in içselci bakış açısının dışına çıkmış olur ancak tekrar hemen geriye içe dönmekte de tereddüt etmez. Ticaret yollarının değişmesi

20 Ülgener, a.g.e., s. 21-22

21 Pirenne, Henri, Hz. Muhammed ve Charlemagne, Ankara, İmge Yayınevi, 2006

22 Abdülkadir Zorlu, "Sabri F. Ülgener'i Yeniden Okumak”, Muhafazakâr Düşünce, Y11 2, Say1 9-10, 2006, s. 191 
Osmanlı dünyasındaki "ortaçağlaşmanın" dışsal bir nedenidir ama Weberci şemaya uygun olarak tek neden değildir ve diğer nedenler içsel olgularda kendisini gösterecektir.

Ülgener statik bir "Ortaçağ" tabiri yerine çok bilinçli bir şekilde bir hareketi, süreci ifade eden ve daha dinamik olan, tarihsel olarak belli bir başlangıç ve son gerektirmeyen "ortaçağlaşma" terimini kullanmayı tercih eder. Ülgener ortaçağlaşmadan bahsederken temel değerleri ve kuruluşlanı dikkate aldığını söyler. Ortaçağ terimi bir tür zorlama ve sunilik havası içindedir ve de kullanıla kullanıla silikleşmiştir. Özellikleri açısından ilk ve yeniçağlara yerleştirilemeyen kuruluşların zorlanarak ortaçağ dönemi içine yerleştirildiklerini söyler. Tarihsel dönemleştirmelerin tarihin belli aşamalarını ifade etmekten ziyade 'yaşayış stilini' 'toplu ve tipik' olarak tasvir etmelerinin daha doğru olacağını düşünür. Böylece Ülgener tarihe belli zorunlu aşamalar çerçevesinden bakan klasik evrimci yaklaşımlarla arasına bir mesafe koymuş olur. Yine de Ülgener tarihi zorunlu olmayan belli aşamalara ayırmanın faydalı olacağına inanır. "Buna nazaran, her çağ kendine göre sosyal düzeni ve sinıf bölünüşü, kendine uygun dünya görüşü ile karakterlenir ve bu karakteristikleri ideal çizgilerine en çok yaklaşan bir vuzuhla nefsinde topladı̆̆ müddetçe ... çă̆ ayrımında kendine ait yeri bulur." ${ }^{23}$

Ülgener için 'Ortaçağ' terimi de belli bir toplum düzeninin ve hayat anlay1şının şekillendirdiği belli bir hayat tarzını veya stilini toplu olarak ifade etmek açısından kullanışlıdır. Ülgener'de Ortaçağ terimi başlangıç ve bitişi belli bir tarihsel dönem olmaktan ziyade İdeal tipik bir tanımlama olarak ortaya çıkar. Bu ideal tipik tarif içinde ortaçağ siyasi veçhesi ile:

"büyük toprak mülkiyeti ve toprağa dayalı hakimiyet şekli (yerine göre çiftlik, mâlikâne veya sadece büyük arazi rejimi); toprağın başladığı ve bittiği sınırla ölçülü bir iktidar dağılışı (merkeziyetsizlk); yine toprağa dayalı bir rütbe ve mansip silsilesi; iktisadi - mali karakteri: Servet belli başlı şekilleri ile toprağa dayalı kaldığı sürece paranın ve menkul değerlerin ikinci planda gelen rolü (ayni iktisat); teşebbüs formları: Şehir dışında ve etrafında tarım (büyük ve küçük işletme şekilleri ile); şehir içinde basit çarşı esnafı ve loncaları (ticaret belli yol kavşakları ve transit merkezleri dışında oldukça sönük). ... hayat ve cemiyet anlayış1...: Başta yine büyük toprak rejimine has ağalık ve eşraflık ruhu; asıl ve neseb iddias1; toprağa dayalı ağır, hareketsiz servet ve kıymet anlayışı (Yeni zamanların menkul servete dayalı, hareketli iş ve çalışma zihniyetinin tam aksi); yine aynı ağırlık ve hareketsizlik içinde; Lonca ahlâkı,

23 Sabri F. Ülgener, İktisadi Çözülmenin Ahlak ve Zihniyet Dünyası, İstanbul: Der Yayınları, 1991, s. 23 
tradisyonalist san'at ve meslek anlayışı. Bütün bu kıymetleri din gayretinden doğan mistik bir havanın çepçevre kuşattığını düşünelim: İşte ortaçağ!"’24

Ülgener saymış olduğu niteliklerin 5. ve 15. asırlar arasında Orta ve Batı Avrupa ve bir kısım Şark memleketlerinde bir araya gelmiş olduklarından dolayı bu döneme ortaçağ denildiğini söyler. Batı'da 13. ve 14. asırlardan itibaren ortaçağa ait hususiyetler tarih sahnesinden silinmeye başlamıştır. Şark'ta ise durum farklı olmuştur. Özellikle Osmanlı devletinin kısa süren askeri ve idari yükseliş devrinden sonra gerileme devri ile birlikte tekrar Ortaçağa veya ortaçağ değerlerine dönüş söz konusu olmuştur. Batı'da yönetimler giderek merkezileşirken Osman11'da uzak vilayetlerdeki isyan ve kıyamların sonucunda merkezi otorite zayıflamış bulunmaktadır. Ticaret imkânlarının daralması ile birlikte, üretim şehir içinde çarşı esnaflığına şehir dışında ise ziraate intikal etmiş bulunmaktadır. Ülgener, $\mathrm{K}$. Breysig'in "her ortaçağ ağalık ve asilzadelik devridir" görüşünün Osmanlı toplumunun temel hususiyetleri açısından geçerli olduğunu düşünür. Ağalık ruhu ve şuuru açısından Osmanlının yeni ortaçağı ile eski ortaçağ arasında her hangi bir fark bulunmamaktadır. Her iki devrin ağalık ve efendilik ruhu da kendisine iş hayatını yakıştıramamaktadır ve hayatın ihtiyaçlarına yönelik üretimi alt sınıflara tevdi etmektedir. Aynı şekilde "asıl ve neseb iddiası, gösteriş hevesi, an'ane ve görenek tarafi da eskisinden farklı değil"dir. Fikir ve sanat hayatı da geçmişten farklı değildir. Hem halk edebiyatı hem de divan edebiyatı feodal zihniyetin kalıplaşmış izlerini devam ettirmektedir. Halk edebiyatı doğrudan feodal zihniyetin akisleri olan hamaset ve destanın bir mahsulüdür. Aynı şekilde divan edebiyatındaki münâcat ve naatlerde dönemin tabakalar arasında aşılmaz sınırlar oluşturan sınıf ve hiyerarşi düzenini görmemiz mümkündür. Ahlak ve mantık anlayışı da sanat ve meslek anlayışından farklı değildir ve geçmişi devam ettirmektedir: "Geleneğe kayıtsız ve şartsız bağlanış; "routine”"den kul kadar ayrılmayış." 25

Ülgener ortaçağ veya "ortaçağlaşma" tabirini "bir tip veya modeli, daha doğrusu yaşama stilini” ifade etmek için kullanır. Yalnız terimler hiçbir şekilde değişmeyen homojen bir kütleyi ifade etmemektedir. Zihniyet seçilen zamana ve çevreye göre değişiklikler sergilemektedir. Bununla alakalı olarak Ülgener zamanın etkisi açısından modern tarihçilerin ortaçağa ilişkin üç aşama arasında gördükleri farklılığa atıfta bulunur. Çevre açısından ise işlek ticaret yollarına yakın ve uzak olan şehirlere ve etraflarındaki geniş tarım alanlarına atıfta bulunur. Netice olarak Ülgener bütün bir çağ 1 ve çevreyi kuşatacak tek bir zihniyetten bahsetmenin mümkün olmadığını söyler. Yine de bütün bu farklılıklara rağmen

24 Ülgener, a.g.e., s. 24

25 Ülgener, a.g.e., s. 24-26 
"temelli ve sürekli çizgiler" bulmanın ve ortak bir çağ zihniyetinden bahsetmenin mümkün olduğunu düşünmektedir. ${ }^{26}$

Ülgener Ortaçağa ait üç aşamanın Türk-İslam medeniyetine de uygulanabileceği görüşündedir. İslam'ın yayıldığı ve şark ticaretinin serpildiği dönemde "liberal-fertçi temayüller" devre damgasını vurmuş bulunmaktadır. Kısa bir süre sonra hemen peşinden ferdi boğan, toprak mülkiyeti esası üzerinde katı hiyerarşik bir cemiyet yapılanmasını getiren koyu ortaçağ dönemi başlamaktadır. Üçüncü aşama ise Batıdakinin aksine akim kalmıştır. Bu aşamanın özelliği toplumun sert ve katı kalıplarını çözerek tekrardan ferdiyetçi-liberal bir anlayışa ve onun aracılı$\breve{g} 1$ ile ticari kapitalist gelişmeye geçit verecek olan ilerici adımların atılmasıdır. Osmanlı toplumunda üçüncü safha bazı nedenlerden dolayı aksamış ve tekrar "toprağa, esnafliğa, esnafça görüş ve düşünüşe, bir kelime ile ortaçağa dönüş" vuku bulmuştur. ${ }^{27}$

Ülgener çevre özellikleri açısından, 14. ve 15. Yüzyıllardaki büyük coğrafi keşiflerin sonucunda ticaret yollarındaki değişmeyi önemli bir amil olarak görür. Ticaret yollarının değişmesi, Yakın Doğu şehir tipleri arasındaki fizyonomi farkl11ıklarının tedricen ortadan kalmasına yol açmıştır. Şehirlerin giderek benzeşmesini ifade etmek için Ülgener Yakın-Asya tipi şehirden bahseden Barthold'a atıfta bulunur: "Bu tipin hususiyeti şunlardır: Şehri garpten şarka ve şimalden cenuba kat'eden büyük cadde boyunca pazar ve şehrin en büyük cami bulunuyordu". ${ }^{28}$ Dapsch'a göre de şehirlerin hukuki niteliğinde değişmeler olmakla birlikte iktisadi fonksiyonları değişmemektedir. Bu şehir tiplerinin giderek benzemelerini sağlayan temel amil olarak, Kemal Karpat, farklı bir olguya vakıf sisteminin etkisine atıfta bulunacaktır. ${ }^{29}$ Vakıf konusuna ileride tekrardan kısaca değineceğiz.

Ülgener Câmi'nin Nefah'at-ül Üns kitabındaki ümera, ulema ve fukara tasnifinden hareketle ümera ile ulemanın aynı sınıf içinde ele alınmasıyla ortaçağ İslam toplumunda içtimai tabakaların "ak ve kara" halinde görülebileceğini söyler. Üst sınıfi teşkil edenler: sırasıyla merkezi otoriteyi temsil edenler, mahalli beyler, eşraf ve ayandan oluşan siyasi iktidar sahipleri, ordu ve idare erkânı, has sahipleri, farklı unvanlara sahip görevliler ve ruhani sınıf ile türlü sebeplerle kayrılmış olan büyük tüccar, toprak ve sermaye sahibi sınıflar. Orta ve aşağı tabakayı oluşturanlar ise yine sırası ile idari ve askeri teşkilatın alt kesimleri, küçük memur ve müstahdemler, tekke ve zaviyelerin müritleri, esnaf ve zanaatkârlar, yerleşik ve

26 Ülgener, a.g.e., s. 27-28

27 Ülgener, Ülgener, a.g.e., s. 28

28 Barthold'dan aktaran Ülgener, a.e.g., s. 29

29 Kemal Karpat, Osmanlı Modernleşmesi: Toplum, Kuramsal Değişim ve Nüfus, Ankara: İmge Kitabevi, 2002, s. 18 
seyyar ticaret erbab1, çiftçi ve rençperlerdir. ${ }^{30}$ Ülgener'in tasnifi her ne kadar Osmanlı sistemindeki askeriye ve reaya ikili ayrımını çağrıştırsa da tabakalar içinde yer alan gruplar açısından farklılık arz eder. Ülgener bu gruplardan ikisi, ticaret ve sanat erbabı üzerinde durmayı önemli görür.

Ülgener analizi açısından büyük tüccarların durumuna büyük bir ehemmiyet atfeder. İslam'ın ilk dönemlerde Yakın Şark'ın başlıca geçiş güzergâhları boyunca canlı bir ticarete sahip olduğu ve ileri bir para ekonomisinin, ticaret ve finans kapitalizminin organlarının ortaya çıktığını söyler. Yine de bunlar zamanla önemlerini giderek kaybetmişlerdir. Ülgener bunun nedeni olarak tüccarların sadece sınırlı merkezler etrafında toplanmış olmasını görür. Şark ticareti geriledikçe bu merkezlerin de ticari önemi giderek azalmıştır.

Ülgener'e göre, Şark dünyasında büyük tüccar Batıdakinin aksine hiçbir zaman şehrin içtimai hayatına damgasını vuramamış ve 'pre-kapitalist' bir iktisadi dünyada bir tür türedi olarak kalmışlar ve "ilk kapitalizmin" alameti olmaktan öteye geçememişlerdir. Küçük tacir ve sanatkârın aksine büyük tüccar hiçbir zaman şehir iktisadının ayrılmaz bir parçası haline gelememiştir. ${ }^{31}$ Tacir ve "bazergân" tabirleri ise anlam daralmasına uğrayarak seyyar satıcı ve çarşı esnafinı ifade etmeye başlamıştır. Ülgener bu vakayı esnaflaşma diye isimlendirir. Ülgener ortaçağın iktisat hayatını ve zihniyetini umumi çizgileri ile aksettiren ve küçük tacir ve sanat erbabından oluşan esnaf zümrelerinin şehir iktisadı ile özdeş hale geldiklerini söyler. Şehrin iktisadi hayatına damgasını vuranlar sayısı oldukça az olan tüccarlar değil bu zümrelerdir. Esnaf zümreleri yarı hamasi yarı dini bağlarla, 'Fütüvvet' veya 'Ahilik' denilen oldukça disiplinli bir teşkilat çatısı altında bir tür kader ortaklığı içinde toplanmış bulunmaktadırlar. Bu teşkilatların derindeki ruh ve zihniyetleri, gayeleri umumi çizgileri ile hepsinde aynıdır: "sanat erbablnı müşterek bir iş ahlakı ve disiplini altında topluca muhafaza etmek; göreneğe (olagelmişe) hakkını tanımak; zaruret olmadıkça iş güç ve sanat değiştirmemek; düşünü gözetip korumak; dışarlya doğru kapanıp beraberce savunmak." ${ }^{2}$

Rekabet kaygısı dışarıya kapanma temayülünü olabildiğince şiddetlendirmektedir. Ahilik ismi daha sonradan ortadan kalksa da, Ülgener'e göre pre-kapitalist zihniyet ufak tefek değişikliklerle çeşitli grup ve zümrelerde aynı surette varlığını asırlar boyunca devam ettirmiştir. Sanat ve ticaretin zamanla esnaflığa meyletmesi zihniyette bir yeknesaklığın ortaya çıkmasının başlıca müsebbibidir. Ülgener'e göre sadece tacir ve esnaf arasında değil görünüşte hiçbir müşterek

30 Sabri F. Ülgener, İktisadi Çözülmenin Ahlak ve Zihniyet Dünyası, İstanbul: Der Yayınları, 1991, s. 30-31

31 Ülgener, a.g.e., s. 32

32 Ülgener, a.g.e., s. 33-34 
noktası olmayan zümreler arasında da zihniyet tekabülü görülmektedir. Ayrı bir hayat tarzına ve görüşüne sahip oldukları aşikâr olan iki birbirinden uzak zümreyi, eşraf ve esnafı karşılaştırır ve farkına varmadan birçok noktada birbirlerine yakınlaşmış ve hatta bitişmiş olduklarının açık bir hakikat olduğunu ifade eder.

"Mesela, şeceresi tarihi veya efsanevi bir kahramana dayanan, muayyen haklar ve imtiyazlarla dışarıya doğru sımsıkı kapalı bir zümrenin mensubu olmaktan duyulan övünme hissi yalnız asıl ve neseb peşinde koşan aristokrat sınıflara münhasır kalmamıştır. Aynı hissi ileride bütün canlılığ 1 ile esnaf topluluklarında da göreceğiz (fütüvvet silsilesi ve fütüvvet gururu!). Kaldı ki, esnaf teşkilatı dahi bitayette (bilhassa ahılık tarzındaki ilk örneklerile) iş ve istihsal tanzimi gibi maddi hayata yönelik maksatlardan çok değişik bir ruh yapısı ile vücut bulmuşlardır. Saiklerini az çok tanıyoruz: Kendi aralarında sıcak ve samimi dayanışma ruhunu muhafaza ve idame; düşküne yardım; misafire ikram vs.. Feodal hayatın üst ve alt farkı bu noktalarda hafiflemiş, hatta silinmiş gibidir. Daha etraflı düşününce, üst ve alt arasında başka benzeyiş noktaları da bulunabilir: Ezcümle, iş hayatile fazla kaygılanmamak, hatta görünüş ve gösterişe düşkünlük yine üst tabakaların malı olmakla kalmamıştır. Aynı ruh ârazını, farklı derecelerde, orta ve aşağı sınıflarda da görebiliriz." ${ }^{\prime 3}$

Ülgener'e göre derin zihniyet farklılıklarına rağmen müşterek temas noktalarının bol miktarda bulunması ortaçağın iktisat ahlak ve zihniyetini insicamlı bir bütün halinde izah edebilmenin yolunu açmaktadır. Hayat şartlarının ayniyetinden kaynaklanan bir durum olarak, esnaf başta tarikatlar olmak üzere diğer zümrelerle başlangıçtan beri öylesine iç içe girip kaynaşmış bulunmaktadır ki birini diğerinden tefrik edilmiş bir halde tanımanın imkânı yoktur. Sadece bir zümreye aitmiş gibi görülen kimi fikirler hakikatte cemiyetin bütününe sirayet etmiş bulunmaktadırlar ve "geniş ölçüde bir ahlak ve zihniyet dünyasından" bahsetmenin mübalağa addedilecek bir yönü yoktur. ${ }^{34}$

Ülgener çözülme devri iktisat ahlakı ile iktisat zihniyeti arasında bir uyumsuzluğun ve hatta karşıtllğın olduğunu söyler. Dönemin insanının iaşe yollarının giderek daralması karşısında loş ve kuytu yollara saptığını ve "kısmet, kazaya rıza, kadere teslimiyet" gibi bildik ortaçağ değerlerinin bu tehlikeli sapmaya giderek daha şiddetli ve sert tepki gösterdiğini söyler. Bir tarafta zapt edilemez bir hırs, diğer tarafta ise katı bir müsamahasızlık yer alır. ${ }^{35}$

33 Ülgener, a.g.e., s. 36

34 Ülgener, a.g.e., s. 37

35 Ülgener, a.g.e., s. 51 
Ülgener dikkatimizi, ortaçağ hayat anlayışının henüz maddeleşmemiş bir dünya görüşü çerçevesinde mana ve hedefini ortaya koymasına çeker. Maddeleşmemeyi Ülgener “(g)ündelik hayatın her türlü hareket ve faaliyet şekillerini iktisadi düşünceden gayri saiklere göre ayarlanmış görmek isteyen bir cemiyet anlayışı" şeklinde tarif eder. Saikler değişmekle birlikte "iktisadi düşünceye ve onun icaplarına sırtını çevirmek noktasında birleşir." Bütün sosyal tabakalar içinde, hamasi, dini ve bedii gibi hayatın renkli tarafını kuru iktisadi mülahazaların üstünde ve önünde tutan bir bakış hayatın merkezinde yer alır. ${ }^{36}$

Ülgener, üst tabakanın sahip olduğu asırlara dayanan ağalık ve efendilik şuurunun bu zümrenin hayat ve cemiyet telakkisini iktisadi kaygılardan uzaklaştırdığını söyler. Ancak iktisadi kaygılardan uzak olmaları onları servet ve altın tutkusundan azade kılmaz. Bu tabakadaki mal ve mülk hırsı kâr ve rantabilite gibi iktisadi sebeplerden kaynaklanmaz. İktisadi faaliyet kendi içinde bir amaç değildir ve "siyasi hayatta paye ve itibar sahibi olmak; debdebe ve saltanat sürmek; unvan ve asalet satmak; 'nam ve nişan' peşinde başkalar ile yarışmak vs." gibi başka maksatlarla gerçekleştirilir. İktisadi faaliyet ve onun sonucu olan mal ve para ağalık ve efendilik şuurunun tezahürleri olan paye, asalet ve gösteriş için vasıta oldukları nispette bir kıymete sahiptirler. Asilzadenin elini paraya sürmesi ancak bir haceti karşılamak veya bir musibeti savmak söz konusu olduğunda makbuldür.

Ülgener, iktisadi faaliyetin değersizliğine ve paranın kirliliğine klasik metinlerden örnek olarak Sadi ve Kınalızade'den alıntı yapar. Özellikle Kınalızade'den yaptığ alıntı devlet ricalinin iktisadi faaliyetten uzak durmasını tavsiye eden bir cümledir: "Emtia ve esbab-ı dünyeviyeye rağbet ve taleb ve tahsil ve iktisabında şevk... eshab-ı devlet ve miknet olanlara lâylk ve müstahsen değildir." ${ }^{37}$ Ülgener bu ifadenin Eski Yunan medeniyetinden gelen bir anlayış olduğunu söyler. Devlet ricalini ekonomik faaliyetten uzak tutan bu anlayışın Batı'da merkantilizm ile birlikte ortadan kalktığını, Osmanlı Devleti'nde ise devletin bir nevi resmi zihniyeti haline geldiğini söyler.

Hakikaten Kınalızade yeni bir görüş ileri sürmüş değildir. Aynı görüşü daha ikna edici şekilde İbn Haldun'un Mukaddime'sinde de görürüz. İbn Haldun devlet ricalinin iktisadi faaliyet içinde yer almasının iktisadi hayatın işleyişi açısından doğuracağı mahzurları büyük bir vuzuhla izah eder. Her şeyden önce devlet ricalinin sahip olduğu devlet imkânları iktisadi rekabette eşitsizliğe ve adaletsizliğe yol açacaktır. Netice bu durum üretici sınıfların ve ticaret erbabının aleyhine

36 Ülgener, a.g.e., s. 53

37 Aktaran Ülgener, a.g.e., s. 55 
ve nihayette iktisadi hayat içinde bir kaosa yol açacaktır. Son olarak da haksız rekabet karşısında kâr imkânları azalan tüccarların ülkeyi terk etmesine ve ülke refahının ve devlet gelirlerinin azalmasına ve devletin çöküşüne neden olacaktır.

Geleneksel iktisat zihniyeti içinde devlete biçilen rol doğrudan iktisadi faaliyet içinde yer almaktan ziyade kurucu, düzenleyici ve koruyucu bir roldür. Burada temel mesele bir liberal olan Ülgener'in geleneksel anlayışı eleştirirken kendi içinde ne kadar tutarlı olduğudur. Liberalizmin 'bırakınız yapsınlar' görüşü ile uyuşmayan bir konumdan eleştirisini yapmaktadır. Sosyalist olarak nitelendiremeyecek olsak da dönemin karma ekonomi anlayışına oldukça yakın durmaktadır. İşin daha tuhaf tarafi eleştirdiği zihniyet iktisadi hayata devletin doğrudan müdahil olmasına karşı çıktığı için Ülgener'in eleştirisine kıyasla liberal doktrine daha yakındır. Şimdilik bu eleştirinin Ülgener'in ne yapmaya çalıştığına dair bize sadece bir ipucu sunduğunu ifade etmekle yetinelim.

Ülgener için üst tabakaların iktisadi faaliyet konusunda menfi bir zihniyete sahip olmaları şaşılacak derecede fazla bir ehemmiyete sahip değildir. Asıl önemli olan bu zihniyetin iktisadi faaliyeti icra edecek olan zümrelerde de aynen bulunmasıdır. Orta tabakayı teşkil eden ticaret ve san'at erbabı da iktisadi açıdan rasyonel olmayan kıymet ve idealleri benimsemiş görünmektedir. Ülgener bu 'iktisat-dışı' karakterin iktisadi zümreler içerisinde en fazla esnaf ve özellikle de ahilerde görüldügünü söyler. Ahiler bir meslek ve san'at topluluğu olmakla birlikte bünyesinde barındırdığ dini, içtimai ve siyasi kıymetlerle tebarüz etmiştir. ${ }^{38}$ Ülgener ahiliğin şekillenmesi açısından ortaya çıktığı 12. ve 13. yüz yılların siyasi kargaşasının içtimai hayat üzerindeki neticelerine dikkatimizi çeker: "dağınık hayat şekillerinden toplu ve kapalı meslek ve tarikat kadrolarına geçiş tarzında hülasa edilebilir" der. Sanat ve tarikat erbabı yaşanan sosyal çalkantılar karşısında kendilerini koruma maksadı ile kapalı cemaat yapılarına iltica etmişlerdir. Devrin temel özelliği ‘kapanma' ve 'cemaatleşme'dir.

Ülgener'e göre fütüvvetlerin, esnaf teşkilatlarının ve de tarikatların oluşmasının temelinde "uzun zaman ve belki bir ömür boyunca bir arada yaşamak, toplu ve beraber çalışmak ve aynı imanı gütmek alışkanlığına, dış muhitin şu veya bu ölçüde baskısı katılınca, o toplulukların her biri(nin) selâmeti büsbütün kendi içine çevrilmek ve kapanmakta" ${ }^{39}$ aramas1 yatmaktadır. Siyasi bir sükûnetin ortaya çıktı̆̆ dönemler de ise iktisadi rekabet kaygısı bu kapalı toplulukların mevcudiyetlerini devam ettirmelerine imkân vermiştir. Korunmak maksadıyla bu içe kapanma ve cemaatleşme söz konusu topluluklara disiplinli bir topluluk ruhu ve belli değer-

38 Ülgener, a.g.e., s. 56

39 Ülgener, a.g.e., s. 57 
ler kazandırmıştır. Bunlar birbirini kollamak ve yardımlaşmak, dış tehlikeye karşı kendilerini topluca savunmak, himayelerine sığınanlara korunma sağlamak vs.dir. Bütün bunlar herhangi bir İktisadi kıymete sahip olmayan değerlerdir.

Ülgener ahlak ve düşüncenin "kapalı ve kendi içine çevrili" bir ahvale bürünmesini de ortaçağlaşma eğiliminin bir ifadesi olarak görür. "O kadar ki, geriden veya dişardan alinan fikirler bu kapalı sisteme ve onun dini-teolojik ifade kallplarına uydurabildiği nispette Ortaçağ ahkâmına mal edilmiş, kısaca ortaçağlaşmış sayabiliriz" der. Ülgener kelimelerin anlamlarının değiştirilerek başlangıçta ifade ettiklerinden tamamen farklı manalarla doldurulduklarını söyler: "Illk defa içtimai-vital saiklerden doğan klymet ve idealler, din ve tasavvuf dünyasına aktarıldıkça, kelime yapısı aynı kaldiğı halde, asıllarındaki renk ve ışık bolluğunu kaybederek kuru, renksiz bir dogmatizme, kapalı bir tevekkül felsefesine çevrilmektedir." " Böylece Ülgener'e göre tasavvuf en itibarlı kelimeleri zühd ve itikaf ölçüleri içinde bu dünyanın inkârını içeren kasvetli bir kadercilikle doldurmakta, manevi hayatımızın ve tefekkürün kuru bir dogmatizm içinde donuklaşmasına yol açmaktadır.

\section{Ülgener ve Weber}

Ülgener her ne kadar Weber'den etkilenmiş olsa da meseleyi ele alışları açısından aralarında bir farklılık söz konusudur. Weber Batı söz konusu olduğunda kapitalizmin gelişmesine yol açan "müspet" unsurlar üzerinde yoğunlaşırken, Ülgener Osmanlı toplumunda "gerilemeye" yol açan "menfi" unsurlar üzerinde yoğunlaşır. Dolayısı ile olumlu olan niteliklerden ziyade olumsuz niteliklere aşırı derecede hassas bir karakter sergiler. Gerçi bu bakış açısı da Weber'den kopuk değildir. Weber'in Batı-dışı toplumları analiz ederken seyrettiği rotaya uygundur. Ülgener, Weber'in Batı-dışı toplumlara yönelik bakış açısını bazı tashihlerle devam ettirmiş olur.

Weber'in bakış açısı oldukça dinamik olan süreci, Batı dışındaki toplumlar açısından oldukça statik bir şekilde görmemize yol açar. Batı-dışı toplumlarda kapitalizmin gelişmesini engelleyen amiller tarih boyunca değişmeden hep aynı kalır. Oryantalizmin durağan doğu anlayışının açık bir yansımasıdır bu. Weber açısından tarihsel gelişmenin tesadüfi sonucu olan gelişmeler, Ülgener'de gerçekleştirilmesi gereken hedeflere dönüşür. Weber için olmuş olan, Ülgener açısından Türkiye bağlamında olması gerekendir. Weber'in çoklu nedensellik anlayışı Ülgener'in çalışmasında, çok sayıda faktörün varlığını kabul etmesine rağmen zihniyet üzerinden büyük oranda tek nedenli bir çözümlemeye dönüşür. 
Ülgener Ahiliği bir tür şövalyelik şeklinde tanımlamaktadır. Fütüvvetler hakkında yazan ilk Avrupalı tarihçilerin 'fetâ' tabirini şövalye anlamında kullandıklarını söyler. ${ }^{41}$ Ahilerin eli bayrak ve kılıç tutan bir tabaka olmaları açısından doğruluk payı taşımakla birlikte Avrupa'da şövalye sınıfı daha çok kırsal alanda yaşayan, askerlik ve siyasetle iştigal eden ancak ekonomik faaliyetle hiçbir ilişkisi olmayan bir tabakadır. Onların Osmanlı toplumundaki karşılığı ancak tımarlı sipahiler olabilir. Avrupa'da şövalye sınıfı içinde vücut bulmuş olan düello gibi belli adetleri Ahilik içinde göremiyoruz. Ahileri Ortaçağ kentlerindeki Weber ve Pirenne'nin analizlerinin bir parçaları yaptıkları tüccarların ve esnafın içinde yer aldıkları kardeşlik teşkilatları ile kıyaslamak daha doğru olurdu. Ülgener Ahilik teşkilatı ile Avrupa'da benzer koşullarda ortaya çıkan (merkezi devletin yokluğu) özerk kent yönetimlerini kuran zümre teşkilatlarını karşılaştırsaydı, Weber'deki çözümlemenin genişliğini ihata etmeye yönelmiş olacaktı ki böyle bir mukayese oldukça değerli olurdu. Ülgener kendi analizini zihniyet ile sınırlandırmasından dolayı, Weber'in Poretestan Ahlakı ve Kapitalizmin Ruhu çalışmasının çerçevelediği sınırlı problematik içinde hapsolmuştur. Oysa analizini Weber'in konu ile irtibatlı diğer ilgi alanlarına genişletmiş olsaydı, benzer hususiyetlere sahip iki olgunun nasıl olup da farklı sonuçlara yol açtığını gösterme imkânına sahip olabilecekti. En azından almış olduğu hukuk eğitimi, Ülgener'e Weber'in Avrupa şehirlerinin tarihini incelerken hukuk üzerinden yaptığ analizlerin bir benzerini gerçekleştirebilme ve kapitalist gelişme açısından Müslüman ve Osmanlı toplumunda hukukun rolünü inceleyebilme imkânını vermekteydi. Hukuk üzerine makaleleri olmasına rağmen, Ülgener hukuk anlayışlarının ve uygulamalarının bu konudaki pozitif veya negatif tesirlerini tahlil etmeyi maalesef gerekli görmemiştir.

Weber ile Ülgener arasındaki farkl11ıklardan birini de ilgilendikleri dini zümreler oluşturur. Weber Hıristiyanlığın değişik mezhepleri arasındaki farklılıkla birlikte Protestanlığın kendi içindeki Kalvinizm, Püritenlik ve Luthercilik gibi değişik şubeleri arasındaki farklılıklar üzerinde de durur. Gerçek Hıristiyanl1$\breve{g}$ ın ne olduğu ve Hıristiyan mezheplerinin sahih inançtan ne kadar ayrıldıkları meselesi ile ilgilenmez. Teolojik bir tartışmanın tarafı olmamaya azami dikkat gösterir. Ülgener ise İslam mezhepleri arasındaki farklı yorumlarla ilgilenmez. Onun yerine tasavvufa ve tarikat zümrelerine ve onların din ve dünya yorumlarını incelemeye yönelir. Weber Hıristiyan mezheplerin Hıristiyan inancını, meslek ve çalışma hayatı ve gündelik hayatın düzenlenmesi açısından nasıl yorumladıklarına ilgi gösterirken, Ülgener sahih İslam inancının ne olduğunu tanımlamaya girişir. Bir tür vaiz konumuna yerleşir. Sosyal bilimci rolünden bir teolog rolüne

41 Ülgener, a.g.e., s. 59 
geçiş yapar. Büyük bir kısmını batini olarak değerlendirdiği tasavvuf okullarını ve tarikatları sahih İslâm'dan bir sapma, İslâm'ın tefessüh etmiş ve ifsata uğramış yorumları olarak ele alır. Ülgener her ne kadar İslâm'ın tek bir renginin olmadığını kendi içinde bir çeşitlilik barındırdığını söylese de, nihayetinde doğru olarak gördüğü riyazetçi yaklaşımı sahih İslâm olarak karşımıza diker. Bunun neticesi, riyazetçi olmayan mistik İslâm yorumlarının tümü aralarındaki farklılıklar dikkate alınmaksızın, İslâm dünyasının gelişmesine ket vuran sapkın yorumlar haline dönüşürler. Oysa Weber mistik ve riyazetçi dinler ayrımını yaparken sahih dinler ile sapkın dinleri birbirinden ayırt etmeyi sağlayacak bir kıstas ortaya koyma maksadı gütmemiştir. Ülgener'in bakış açısı İslâm coğrafyasını ve tarihini sahih inancın sonraki dönemlerde sınırlı zümreler içinde oldukça mahdut kaldığı ve tüm toplumun sadece İslâm'ın ilk döneminde böyle bir inanca sahip olduğu bir tasvir ortaya koyar. Sahih inancı temsil eden mezhepler bile tasavvufu aşıp geniş halk kitlelerine ulaşamazlar. Hiçbir şekilde popüler bir karakter kazanamazlar.

Ülgener'in İslâm'a bakışını kısırlaştıran Weber'in İslâm konusunda büyük oranda tekçi olan perspektifi olmuştur. Her ne kadar Ülgener Weber'in İslam hakkındaki yanlış değerlendirmelerini düzeltmek için büyük bir çaba sarf etmiş olsa da sonuçta değişen pek bir şey yoktur. Weber'in dediği her şey büyük oranda haklı çıkar. Ülgener sadece sürecin öznesini değişmiş, İslâm yerine tasavvufu ikame etmiştir. Böylece Ülgener Weber'in görüşlerini restore ederek tadilattan geçirmiş onları ne radikal bir şekilde sorgulamış ne de reddetmiştir. Daha geçerli olabileceklerini düşündüğü bir alana taşımıştır. Ülgener daha çok, İslâm söz konusu olduğunda Weber'in kendi metodolojisini takip etmeyi bırakıp tutarsızlık sergilemesi eleştirmektedir. ${ }^{42}$

\section{Ülgener ve Sombart}

Olguları ele alışıyla, Ülgener'in sunduğu perspektife bir alternatif teşkil ediyor olmasından dolayı Sombart'a başvurmamız faydalı olacaktır. Sombart modern kapitalizm anlayışının şekillenmesinde oldukça önemli olan bir simadır. Fernand Braudel kapitalizm teriminin geniş anlamı ile XX. yüzyılın başına ait olduğunu söyler. Braudel kavramın gerçek anlamda ortaya çıkışını Sombart'ın 1902 tarihli Der moderne Kapitalismus kitabının çıkışına borçlu olduğumuzu ve Marx'in bu sözcükten habersiz olduğunu iddia eder. ${ }^{43}$

Ülgener kullandığı yöntem açısından sıkça Sombart'a referansta bulunmasına rağmen Sombart'ın kapitalizm ve tüketim arasındaki ilişkiye dair oldukça

42 Ülgener'in Weber'e yönelik eleştirileri için, Din ve Zihniyet, 2006, s. 55-64

43 Fernand Braudel, Kapitalizmin Kısa Tarihi, Ankara, Say Yayınları, 2014, s. 47 
dikkat çekici ve etkileyici bir tarzda eğilen çalışmalarını görmezlikten gelmiştir. Sombart modern kapitalizmin ortaya çıkmasında iki unsurun oldukça etkili olduğunu söyler. Bunlardan biri modern düzenli orduların ortaya çıkmasıdır. Diğeri ise Avrupa toplumunda haçlı seferlerinden sonraki devirlerde kadın ve erkek arasındaki ilişkinin mahiyetinin değişmesine bağlı olarak üst sınıfların hayat tarzının aşırı bir lüks tüketim içerecek şekilde değişmesidir. ${ }^{44}$ Sombart tarihte sadece tek bir coğrafyada Avrupa'da olağan üstü bir çapta böyle bir lüks selinin yaşandığını söyler. Öyle ki servetin el değiştirmesini, aristokrasinin elinden burjuvazinin eline geçmesini sağlayacak derecede büyük bir lüks tüketime yönelme söz konusu olmuştur. Sombart'a göre, bu lüks tüketim, talebi karşılamak için üretimde bir patlamaya yol açmış ve kapitalizmin gelişmesi açısından oldukça teşvik edici olmuştur. Sombart'ın çizmiş olduğu çerçeveyi takip edecek olursak, Osmanlı toplumu açısından mesele Ülgener'in bakış açısının savunduğundan farklı bir yöne doğru kayar. Ülgener için üst sınıfların ve onları taklit eden orta sınıfların üretmeden lüks bir hayat yaşama arzusu ve israfa yönelmeleri ekonomik gelişmenin önünde bir engel teşkil etmiştir. Oysa Sombart'ı izleyecek olursak Osmanlı toplumu açısından problem lüksün olması değil, tüccar ve üretici güçleri yeterince teşvik edecek düzeyde yüksek boyutlara varmamış olmasıdır.

Sombart Avrupa'da ortaya çıkan büyük kent olgusunu da üretim ve ticaretten ziyade doğrudan tüketimle ilişkilendirir. Sombart "en büyük kentler, en büyük (ve en çok sayıdaki) tüketicilerin ikametgâh bölgeleri oldukları için büyüktür; şu halde kentler, esasen yapılarının genişlemesini, ülkenin kent merkezi noktalarındaki tüketimin yoğunlaşmasina borçludur" 45 demektedir. İngiltere'de " $k r a l$, ana kraliçe ve veliahdın aşağı yukarı bütün tüccarların toplam gelirleri kadar yiyip bitirdikleri ve insan besledikleri bir gelirleri vardl." "...erken kapitalist dönemin sonuna kadar süren kapitalist gelişimden büyük ölçüde lüks” sorumludur. “... hemen hemen bütün Avrupa sömürgelerindeki üretimin öncelikle yüksek değerli lüks mal üretimi olduğunu görürüz." "Paris ve Londralı küçük hanımefendilerin, keyiflerini tatmin etmek için bu devasa siyahlar ordusunu dize getirmiş olması, doğrusu tahrik edici bir düşüncedir." Sombart'ın siyahlar ordusu diye bahsettiği toplam köle sayıs1 6.822.759'dur. “...lüks talebini karşılamak üzere sayısız endüstriye yaşam kazandırıldiğını, yani birçok endüstriye "lüks endüstrisi” demek gerektiğini..." Sombart'tan yaptı̆̆ımız bütün bu alıntıların gösterdiği şey kapitalist gelişmeye bir temel olarak Ülgener'in inşa etmek için çaba sarf ettiği çalışma ve üretim ethosunun tüketim bir kenara bırakıldığında hiçbir anlam taşımadığıdır.

44 Werner Sombart, Aşk, Lüks ve Kapitalizm, Ankara, Bilim ve Sanat Yayınları, 1998, s. 8

45 Alıntılar için sırası ile Sombart, a.g.e., 39, 53, 158, 188, 191, 192 numaralı sayfalara bakılabilir. 


\section{Genel Bir Değerlendirme}

Genel olarak Türk tarih yazıcılığının temel eksikliklerinden birisi Osmanlı devletini sadece Müslüman Türklerden müteşekkil etnik ve dini bakımdan homojen bir yer olarak görmesidir. Bu milliyetçi veya Türkçü akımların tarih yazımı üzerindeki olumsuz bir etkisi olarak görülebilir. Osmanlı toplumunun daha bütüncül ve tam bir tablosunun ortaya konulabilmesi için her bölgede Müslümanlarla birlikte yaşayan gayri-Müslim unsurların da dikkate alınması gerekir. Bütün etnik ve dini unsurları birbirine bağlayan bağ dinin dışında başka bir amil olan siyasettir. Türk tarih yazımı genellikle gayri-Müslim unsurları ihanetle ilişkilendirildikleri belli bir tarihten öncesi için görünmez kılmıştır ve mevzuyu sessizce geçiştirmiştir.

Gayri-Müslimler karşısında sergilenen kayıtsılılı̆̆ın aynısını Ülgener'de de görürüz. Aslında Ülgener bu mevzunun kıyısına kadar gelip üzerinden atlamıştır. Çalışma ve çözümleme sahasını "Yakın Şark dediğimiz geniş medeniyet dünyası içinde Türk halkının ve kültürünün mukadderatile birinci planda alakalı sahalar" ${ }^{\prime 4}$ şeklinde sınırlandırır. Ülgener, farklı kültür sahaları ve medeniyetlerden bahseder. Bunların kesin sınırlarla birbirinden ayrılmadığını aralarında "tesir ve aksi tesirlerin tarihte daima" görüldüğünü ifade eder. Ağırlıklı olarak kullanacağ 1 kaynakların "Türk-İslam” kaynakları olacağını söyler. Osmanl1-Türk düşüncesi üzerindeki etkileri açısından İbn Haldun ve Feridüddin Attâr'1 kullanacağı kaynaklar arasında komşu kültür veya medeniyetlere ait simalar olarak sunar. Devamla, "Yakın Şark tipinde şehirlerin az çok müşterek hayat ve zihniyet tarzına sahip oldukları düşünülürse, o şehirleri velev ayrı lisan ve kültür çevreleri içinde temsil eden fikir adamlarının aynı sonuçlarda birleştikleri anlaşılır" ${ }^{\prime 47}$ diyerek birinin diğerinin yerine ikame edilmesinin daima mümkün olduğunu ifade eder. Ülgener, aynı şartları haiz olan komşu medeniyetlerin sanat ve fikir temsilcilerinin dinlenilmesinin faydalı olacağını söyler. Bunun faydası "belirtilen bir ruh halinin tek, arızî olmakla kalmayıp köklü ve yaygın bir zihniyetin ifadesi olduğunu anlamak" olacaktır. Ancak burada bir belirsizlik vardır. Attâr ve İbn Haldun hangi zihniyetin mümessilleridirler? Esnaflaşma veya ortaçağlaşma dediği 'pre-kapitalist' zihniyetin birer temsilcileri midirler yoksa daha önceki zihniyetin temsilcileri mi? belli değildir. Aynı belirsizlik Mevlana'dan yapmış olduğu iktibaslarda da kendisini gösterir. Ortaçağlaşmayı ifade eden zihniyet unsurlarına Ortaçağ öncesinin düşünürlerinden misaller getirir.

46 Sabri F. Ülgener, İktisadi Çözülmenin Ahlak ve Zihniyet Dünyası, İstanbul: Der Yayınları, 1991, s. 38

47 Ülgener, a.g.e., s. 39 
Nasıl ki Osmanlı devletinde gayri-Müslimleri çalışırken, geniş Müslüman kitle ile olan ilişki ve etkileşimlerini göz ardı etmek doğru bir yaklaşım olmayacaksa, aynı şekilde sınırlı alanlar dışında, Müslüman Osmanlı tebaasını çalışırken de gayri-Müslim unsurlar ile olan ilişkilerini de dikkate almak gerekir. Her ne kadar bazı tarihçilerin söylediği gibi ayrı "kompartımanlar" içinde yaşadıklarını kabul edecek olsak bile -Osmanlının temel siyaseti birbirlerine karışmalarını ve birbirleri içinde asimile olmalarını engellemeye yönelikti- yine de aralarında hiçbir etkileşimin olmadığını kabul etmek mümkün değildir. Bu etkileşimin açıkça görüldügü alanlar olarak müzik, sofra kültürü, karagöz, kahvehane kültürü, sivil mimari vb. gibi olguları gözümüzün önüne getirebiliriz.

Maddi kültürdeki benzeşmelere bağlı olarak zihniyet dünyasında da belli benzerliklerin olabilmesi gerektiği rahatlıkla farz edilebilir. Özellikle de İstanbul'a gelen Avrupalı seyyahların bir Ermeni ile bir Müslüman Türkü birbirinden tefrik etmede ne kadar zorlandıklarını hatırlayacak olursak. Ancak bizi burada Ülgener'in çalışması ile alakalı olarak gayri-Müslimlerin iktisadi hayatı ilgilendirmektedir. Gayri-Müslimlerin iktisadi hayattaki etkinliklerinin artması ve Müslümanların önüne geçmeleri Tanzimat'ın hemen öncesinde ve sonrasında Avrupa ile artan ilişkilerin bir neticesi olarak değerlendirilebilir. Tanzimat öncesine ait pek fazla araştırma olmamakla birlikte, durumlarının Müslümanlardan çok fazla farklı olmadığını düşünmememiz için bir sebep yok. En azından bir sanayi devrimi gerçekleştirmediklerini biliyoruz.

Eğer bariz bir farklılık yoksa bunun Ülgener'in analizi açısından ayrıca izah edilmesi gereken bir problem alanı oluşturması kaçınılmazdır. En nihayetinde gayri-Müslim ve Müslüman tebaa şehir merkezinde çarşıda aynı iktisadi hayatı paylaşmaktadırlar. Eğer Müslümanların iktisadi hayattaki geri kalmışlıkları tasavvuf üzerinden açıklanacaksa, aynı coğrafyada yaşayan Hıristiyanların ve Yahudilerin durumunu nasıl açıklayacağız? Bu başlı başına cevaplanması gereken bir soru olarak orta yerde durmaktadır. Belki bu noktada siyaset açıklayıcı bir unsur olarak ele alınabilir. Ülgener "siyasi engellere 'hızlandırıcı' ve 'tamamlayıcı' faktör" ${ }^{\prime \prime 8}$ şeklinde atıfta bulunsa da siyasi amilleri yeterince ve derinlikli bir şekilde analiz etmemiştir.

Ülgener'in hamaset ve destanın sadece ortaçağın feodal zihniyetine ait olduğu, iddiasının da geçerliliği oldukça şüphelidir. Ortaçağ öncesi istila dönemlerinin yağmacı hayat tarzları içinde bunların oldukça parlak örneklerine tesadüf etmemiz hiç de zor olmayacaktır. Her şeyden daha fazla yağmacı bir hayat, kahramanca eylemlere daha fazla ihtiyaç duyar ve şiirinde bunu yansıtır. Ancak bunun mo- 
dern dönemler için de geçerli olduğunu söylemeliyiz. Hiçbir şekilde geleneksel olarak göremeyeceğimiz tamamen modern bir olgu olan milliyetçilik hareketlerini düşünmemiz yeter. Aynı şekilde nesep iddiası da ortaçağ öncesi dönemlere rahatlıkla götürülebilir. Daha eskinin yönetici sınıfları içinde soylarını tanrılara dayandıran gruplar çok sık olarak karşımıza çıkmaktadırlar. İş hayatını kendisine yakıştıramayan efendilik ve ağalık şuuruna sahip sınıfların varlığı da hiçbir surette sadece ortaçağa ait olarak görülemezler. Gösteriş hevesini de sadece ortaçağa ait bir hususiyet olarak göremeyiz. Gösteriş olgusu ortaçağın öncesinde olduğu kadar, günümüz açısından da, sosyal bilimlerde tüketime ilişkin yapılan hararetli tartışmalardan anlaşılabileceği gibi, oldukça geçerli bir olgudur. Hakikatte neyin tamamen ortaçağa ait olduğu ve neyin daha önceki dönemlerden kendisine miras kaldığ 1 konusunda daha dikkatli olmak gerekmektedir. Ayrıca Ülgener'in ortaçağa atfettiği tüketim ve gösteriş olgusunun modern dönemde tekrardan bütün şatafatıyla dirildiğini bu konuda yapılan sosyolojik çalışmalardan biliyoruz. Ülgener'in perspektifinden durumu değerlendirecek olursak modern dönemler açısından da kısmi bir ortaçağlaşmadan bahsetmemiz gerekir. Hadisenin ideal tipik bir düzeyde ele alınması kendi başına meseleyi hal etmeye hiçbir surette yeterli değildir.

Ülgener'e göre her ne kadar aynı şehirde bile, farklı sınıf ve zümrelerin hayat telakkisinden dolayı tek bir zihniyet söz konusu olmamasına rağmen, bu iki olgu kaba ve genel çizgiler içerisinde de olsa ortak bir zihniyetten bahsetmeyi mümkün kılmaktadır. Gramsci'ye atıfta bulunacak olursak, Ülgener cemiyette kendi hegemonyasını oluşturmuş bir dünya görüşünün diğerleri karşısındaki üstünlük ve önceliğinden bahsetmektedir. Ülgener Marksizmle arasına koymuş olduğu mesafeyi daha dar tutmuş olsayd1, bahsettiği zihniyetin oluşumunda siyasetin rolüne dikkatini daha fazla yönlendirebilirdi. Oysa Ülgener nedensellik zincirinin bir noktada sona ermeyeceğini söyleyerek zihniyeti verili bir olgu ve temel belirleyici neden olarak ele almayı tercih eder.

Ülgener iktisadi faaliyetin kâr maksatlı kendi içinde bir amaç olması gerektiğini düşünerek onu fetişleştirme eğilimi taşır. Bu nokta Ülgener ve Veblen'i oldukça birbirine yaklaştırır. Tarih içinde hiç bir dışsal amaca boyun eğmeden sadece kendisini hedefleyen bir iktisadi çalışma düzeni her hangi bir yerde ortaya çıkmış mıdır? sorusu oldukça anlamlı olacaktır. Özellikle de bu soruyu Kalvinizm'e yöneltmemiz bariz bir manidarlık taşıyacaktır. Weber'e göre Modern Kapitalist zihniyetin oluşmasında oldukça etkili olan Kalvinizm'in bile iktisadi faaliyeti dişsal bir amaçtan yoksun kendi başına bir amaç olarak görmediğini iddia edelim. Protestanları yoğun bir iktisadi faaliyete iten temel saik ve müşevvik öbür dünyada ruhun selamete ermesindeki seçilmişlik dürtüsüdür. Bunun ne kadar iktisadi ve rasyonel bir amaç olduğu düşünülebilir. 
Ancak Ülgener'in temel meselesi istihsalde ortaya çıkan fazla değerin nereye yönlendirileceğidir. Ülgener'in bir nebze kastettiği şey fazla değerin başka alanlardan ziyade tekrardan üretime sarf edilmesidir. Ancak böyle bir durum, Weber'i dikkate alacak olursak, Kalvinizm'in tesiri altında sadece modern Kapitalizmin ve kapitalist zihniyetin oluşumu safhasında vuku bulmuştur. İşin ilginç yanı, üretimin rasyonelleşmesinin birçok sosyoloğun irrasyonel olarak göreceği dünyevi olmayan bir uhrevi kurtuluş saiki ile gerçekleşmiş olmasıdır. Bu saik ortadan kalkar kalkmaz, fazla/artı değerin bir kısmı tüketime yönelmiştir. Ülgener'in temel eksiği büyük çaplı tüketim olmaksızın nihayetsiz bir üretimin olabileceğini varsaymasıdır. Günümüzde kâr olgusu sınırsız üretimden ziyade sınırsız tüketimle ilişkili hale gelmiştir. Ancak kapitalizmin gelişme safhasındaki durumun farklı olduğunu düşünebilir miyiz?

Osmanlı toplumunda bir durağanlıktan bahsedeceksek bunu Osmanlı toplumsal siyasetinin başarısız olmasında değil aksine başarısında görmemiz gerekir. Osmanlı toplumsal siyasetinin temelini geleneksel daire-i adliyye teorisinde de idealize edilen, toplumu istikrarlı bir denge içinde tutma anlayışının oluşturduğunu söyleyebiliriz. Ekonomik zihniyetin yanı sıra siyasi zihniyetin de analiz içine dahil edilmesi gerekmektedir. Ekonomik bir analizden ziyade siyasi iktisadi (ekonomi-politik) bir analiz daha açıklayıcı olabilir. Osmanlının topluma yönelik siyaseti ile ekonomik sistemini birlikte düşünmeliyiz. Ancak Ülgener'in bu konuya ilgisi oldukça sınırlı kalır. Osmanlı Devletinin tüccar karşısında tüketiciyi korumaya yöneldiğini söyler. Oysa dönemin genel zihniyetin yanı sıra devletin siyaset ve adalet zihniyetinin ekonomi ile olan ilişkisinin daha geniş bir şekilde analiz edilmesi gerekmektedir.

Müslüman toplumlarda kapitalist gelişme açısından dikkate alınması gereken olgulardan biri olarak vakıf müessesesinin değerlendirilmesi gerekmektedir. Bu Ülgener'in dikkat etmediği bir husustur. Vakıf müessesesinin Georges Bataille'ın Lanetli Pay (1999) eserinde ortaya koyduğu problematik çerçevesinde incelenmesi faydalı olabilir. Bataille'nin temel problemi farklı toplum tiplerinde ekonomideki fazla/artı değerin hangi alanlara kanalize edilerek yok edildiğidir. Bataille'a göre Meksika'nın Aztek toplumunda dini kurban törenlerine, Kuzey Batı Amerika yerlilerinde potlaça, Tibet'te toplumda büyük bir kitleyi oluşturan rahipler sınıfına, modern Batı toplumlarında ise sanayi üretiminin ihtiyaçlarına ve finansmanına üretimin ihtiyaç fazlası aktarılmaktadır. İslam için bu aktarım büyük askeri seferlerin organizasyonuna gitmektedir demektedir. İslam için söylediğinin doğruluk ve yanlışlı̆̆ını tartışmayacağız ancak böyle bir 'yok etme' işlemini vakıfların yapıp yapmadığını kısaca tartışmakta ve konunun uzmanlarının alakasını bu noktaya yöneltmekte fayda var. 
Her ne kadar çağdaşımız birçok kişi vakıfları devletten servet kaçırmanın pratik bir yolu olarak değerlendirse de durumun bunun ötesinde olduğu inkâr edilemez. Her şeyden önce devletin bu konudaki iradesi elde edilen servetlerin buraya tahsis edilmesine yol açmaktadır. Öncelikle vakfı kuran kişinin vakıfta kendi soyundan gelen kişileri vazifelendirmesi onların tasarrufuna vakfın mülkiyetini değil gelirlerinin sınırlı bir kısmını bırakmaktadır. Vakıflar diğer faaliyetlerinin yanı sıra Osmanlının sivil inisiyatif yoluyla gerçekleştirdiği bir sosyal politika olarak değerlendirilebilir. Kişisel menfaatle amme menfaatinin birleştirildiği bir sistem oluştururlar. Ancak bu hudut içinde belli bir servete ulaşmış insanlar elde ettikleri bu serveti vakıf müessesine aktarabilirler. Aynı zamanda daha küçük birikimlere sahip insanlarında hayır maksadıyla arsa ve belli emlaklarını vakfedebilmektedirler. Buralara akan finansmanın toplam ekonomi içindeki çapının ne olduğunun tespit edilmesi gerekmektedir ki bu bize doğrudan iktisadi faaliyetin dışına ne kadar bir fazlanın aktarıldığını ve kapitalist bir ekonominin gelişmesi üzerinde ne tür bir etkide bulunduğunu göstersin.

\section{Sonuç}

Bütün azamet ve haşmetine, bütün bir titizlik ve ihtimamına rağmen Ülgener'in tahlili tek ayağı üzerinde koltuk değneği ile sekerek yürüyen bir analizdir. Kapitalizmin gelişmesi açısından sadece üretime ve ticarete vurguda bulunması, tüketim, israf ve lüksü sadece engelleyici menfi unsurlar olarak görmesi, kapitalist üretimin gelişmesi açısından yapmış olduğu teşvik edici pozitif işlevi, bütün Sombart aşinalı̆̆ına rağmen, görmezlikten gelmesi böyle bir sonuca yol açmaktadır. Aslında bu görmezlikten gelme oldukça kasitlı bir niteliğe sahip de olabilir. Ülgener'in temel gayesi Türk insanını içinde bulunduğunu düşündüğü kayıtsızlık ve uyuşukluktan uyandırmak ve ekonomik hayat içinde daha aktif bir fail haline getirmektir. Ancak bütün bir devrin hayat tarzını ve zihniyetini açılamaya niyetlenen bir sosyal analizin bu derece ehemmiyetli bir olguyu göz ardı etme lüksü olamaz.

Marksizm'den uzak durmasına rağmen Ülgener'de Marksist işlevselciliğe benzer bir işlevselci yaklaşımın varlığını görebiliriz. Marksist işlevselcilik bütün toplumsal ilişkilerin ve olguların değerlerinin çalışma, emek ve üretim ilişkileri, yani ekonomi açısından doğurdukları sonuçlara göre dikkate alınmasıdır. Özellikle Frankfurt Okulu teorisyenleri bu tür İşlevselcilik içinde kültürü ele alarak, kültürün yukardan manipüle edildiği tamamen bütünleşmiş bir toplum görüntüsü sundukları için eleştirilmişlerdir. ${ }^{49}$ Benzer şekilde Ülgener'de de her şeyi çalışma

49 Axel Honneth, "Eleştirel Teori”, Günümüzde Sosyal Teori, edt. Anthony Giddens \& Jonathan Turner, Ankara: Say Yayınları, 2013 
ve üretim açısından değerlendiren bir işlevselci yaklaşım görüyoruz. Adorno ve Horkheimer'da gördüğümüz daha önce hiç olmadığı kadar tamamen bütünleşmiş ve birleşmiş bir kültürün her şeye benzerlik bulaştırmasına ${ }^{50}$ benzer şekilde Ülgener'in analizinde tasavvuf her şeye benzerlik bulaştırarak kültürel alanda toplumsal bütünleşmeyi sağlamaktadır. Yalnız Ülgener'in zihniyeti ele alışı Frankfurt Okulunun kültürü ele alışından farklılık göstermektedir.

Ülgener için zihniyet yukardan üst sınıflar tarafindan kasıtlı olarak manüpüle edilen bir olgu değildir. Doğrudan sivil hayatın içinde şekillenmiştir. Ancak bu yaklaşım farkı farklı sonuçlara yol açmamaktadır. Netice de her ne kadar Ülgener tek bir zihniyetin olduğunu söylemese de diğer zihniyetlerin toplumdaki hâkim zihniyetin karşısında pek bir varlık gösteremediklerini dolayısı ile ilgilendiği konu açısından ayrıca tahlil edilmeyi gerektirmediklerini düşünür. Nihayetinde büyük oranda tasavvufun şekillendirdiği tek bir zihniyet toplumun bütünü üzerinde mutlak bir hakimiyet kurarak her şeyin değerini takdir eder, insan ilişkilerini ve bireylerin davranışlarını belli bir istikamete yönlendirir. Toplum zihniyet üzerinden tamamen bütünleşmiş yekpare bir yapı suretine bürünmüş olur. Ülgener bir sistem sosyoloğu değildir, ancak sistemik bir bakış açısına meyilli görünür. Parsons'ın kendi yaklaşımını ifade etmek için kullandığı tabiri Ülgener için de kullanabiliriz: "kültürel determinizm. Merton açısından değerlendirecek olursak ekonomi açısından tamamen bozuk bir işlev (dysfunction) sergileyen bir zihniyetin asırlar boyunca varlığını nasıl devam ettirdiğini izah edebilmemiz oldukça güçtür. Ülgener bu zorluğun üstesinden gelebilmiş midir, bunun cevabı oldukça su götürür. Üngener'in tek yönlü işlevselciliği, Merton'ın pozitif işlev dediği sonuçları dikkate almamaya kendisini götürür. Tek boyutlu analizin sonucu toplumun tamamen patolojik bir karakter içinde tasviridir. Geleneksel Osmanlı toplumu basit illiyet bağlarını kurma melekesinden ve mantıktan mahrum insanların irrasyonelliğinin cisimleşmesi olarak tasvir edilir. Bunun toplumun büyük bir kıs$\mathrm{m} 1$ açısından sonucu genelleşmiş bir anomi durumudur. Ahlaki ilkelerle gündelik hayat içindeki kültürel hedefler arasında zihniyet üzerinden kurulan uyuşmazlık yüzy1llar süren genel anomik bir duruma yol açar. Toplumun bir çözülme sürecini yaşamaktan ziyade çoktan çökmüş olması gerekmektedir. Ülgener'in modeli içinde hiçbir surette göz ardı edilemeyecek teorik kusurlar barındırmaktadır. Ülgener analizinin teorik zaaflarının ve eksiklerinin üstünü maharetle kullandığı bir belagatle ustaca örter.

Ülgener'e modern insana atfettiği özellikler ve bunları idealleştirmesi üzerinden baktığımızda sanki karşımızda ters yüz edilmiş bir Tönnies durmaktadır. 
Ülgener, dünyayı sadece zihninde soyut ilişkiler yumağı halinde yaşayan bir insan tipini idealize etmektedir. Ülgener'in modern insan tasavvuru sadece Weberci manada bir "ideal tip" değil aynı zamanda sıradan anlamı ile "ideal" tiptir, ulaşılması gereken ideal insan tipidir. Ülgener sadece bilimsel bir analiz yapmamaktadır, bize ahlaki bir ideal sunmaktadır. Yazma stili açıkça kendini ele verir. Modernlik tiplemeleri insanları ikna etmeyecekse, geçmişin daha geçmişine giderek modernliğin (kapitalizmin) köklerini İslam'ın başlangıç dönemine yerleştirerek geleneksel dünyayı eleştirmek ikna edici olacaktır. Zaten bütün Müslümanlar asr-1 saadetin diğer bütün dönemler karşısında üstünlügünü kabul etmektedir. Dolayısı ile hakiki İslâm ile kapitalizmin dünya görüşünün aynı amaçları güttügünü söylemek stratejik bir üstünlük sağlayacaktır. Herkes İslam'ın gelişmeye -Ülgener için bu kapitalistleşmek demektir- engel olmadığını duyunca avuçları patlayıncaya kadar alkışlayacaktır ve tarihsel bir kompleksten bir anda kurtulacak, özgürleşecektir. Ama yine de suçlunun bulunması gerekmektedir. Suçlu ilk dönem hariç bütün bir tarihin kendisidir, gelenektir, tasavvuftur, ahiliktir, esnaftır, dönemin değerleri ve zihniyetidir. Geriye pek bir şey kalmamıştır. Apolojist bir tavır bütün bir geçmişi kalkınma adına marazileştirir. Ülgener'in İslâm'ın kapitalizme uygun yeni bir teolojik okumasını teklif ettiğini söyleyebiliriz. Gerçi Ülgener için bu okuma yeni bir şey olmaktan ziyade İslâm'ın başlangıçtaki asli tavrına ait olan bir okumadir.

Ülgener'in çalışması 'Ortaçağ' zihniyetini teşkil eden ve günümüzde de henüz tamamen ortadan kalkmış görünmeyen tasavvuf retoriğini (söylemini de diyebiliriz) çözmeye yönelik titizce dokunmuş ve oldukça mahir retorik bir saldırı olarak değerlendirilebilir. Eğer tekke yoksa hırs, tamah, bencillik serbest kalacaktır, böylece liberalizmin kazanç arzusu ile tutuşmuş hesapçı rasyonel bencil bireyi ortaya çıkabilecektir. Tekke liberal bir birey önündeki en önemli engeldir. Liberal bireyin doğabilmesi için tekkenin yıkılması gerekmektedir. Bu da bize Ülgener'in siyasi-toplumsal amacını gösterir.

Ülgener'i sosyolojik teori içinde bir yere yerleştirmeyi deneyecek olursak, Ülgener'in az gelişmişlik ve kalkınma meselesi ile ilgilenen bir modernleşme teorisyeni olduğunu söyleyebiliriz. Her ne kadar yapısal-işlevselcilikle bir bağı olmasa da, kültür ve insan tipi üzerindeki vurgusu ve bunların iktisadi kalkınma acısından önemine olan ilgisi ve geleneksel hayatın kalkınma açısından doğurduğu problemlerle ilgilenmesi ve Weberci bir temele sahip olarak gelişmeyi büyük oranda içsel faktörler açısından değerlendirmesi Ülgener'i modernleşme teorisyenleri ile yakınlaştırmaktadır. 


\section{Kaynakça}

Adorno, Theodor W., Kültür Endüstrisi: Kültür Yönetimi, İstanbul, İletişim Yayınları, 2009.

Ayan, Dursun, "Sabri F. Ülgener' in Türk Düşünce Kültüründeki Yeri”, Doğu Batl, y11 3, say1 12, 2011.

Honneth, Axel, "Eleştirel Teori”, Günümüzde Sosyal Teori, ed. A. Giddens, J. Turner, Ankara, Say Yayınları, 2013.

Bataille, Georges, Lanetli Pay, Ankara, Mor Yayınları, 1999.

Braudel, Fernand, Kapitalizmin Kısa Tarihi, Ankara, Say Yayınları, 2014.

İbn Haldun, Mukaddime-I, İstanbul, Milli Eğitim ve Gençlik ve Spor Bakanlığı Yayınları, 1988.

Karpat, Kemal, Osmanlı Modernleşmesi: Toplum, Kuramsal Değişim ve Nüfus, Ankara, İmge Kitabevi, 2002.

Ülgener, Sabri F., İktisadi Çözülmenin Ahlak ve Zihniyet Dünyası, İstanbul, Der Yayınları, 1991.

, Zihniyet ve Din: İslam, Tasavvuf ve Çözülme Devri İktisat Ahla$k l$, İstanbul, Derin Yayınları, 2006.

Pirenne, Henri, Hz. Muhammed ve Charlemagne, Ankara, İmge Yayınevi, 2006.

Sombart, Werner, Aşk, Lüks ve Kapitalizm, Ankara, Bilim ve Sanat Yayınları, 1998.

Weber, Max, Şehir: Modern Kentin Oluşumu, Bakış Yayınları, 2000.

Zorlu, Abdülkadir, "Sabri F. Ülgener'i Yeniden Okumak”, Muhafazakâr Düşünce, y11 2, say1 9-10, 2006. 
